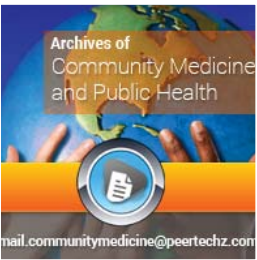

\title{
Medical Group
}

\section{Archives of Community Medicine and Public Health}

\section{Edmund Ndudi Ossai*, Nelson C Eze, Okwudiri Chukwu, Ugochinyere A Uguru, Ezinne $\mathrm{C}$ Ukpai and Ezeogo Ihere}

Department of Community Medicine, College of Health Sciences, Ebonyi State University Abakaliki, Nigeria

Dates: Received: 02 January, 2018; Accepted: 12 January, 2018; Published: 16 January, 2018

*Corresponding author: Edmund Ndudi Ossai, Department of Community Medicine, College of Health Sciences, Ebonyi State University Abakaliki, Nigeria, Tel: +234803 6675417; E-mail: ossai_2@yahoo.co.uk

Keywords: Knowledge; Practice; Blood donation; Undergraduates; Ebonyi state; Southeast Nigeria

https://www.peertechz.com
Research Article

Determinants of practice of blood donation among undergraduate students of Ebonyi State University Abakaliki, Southeast Nigeria

\section{Abstract}

Objective: Aim of study was to determine the factors affecting the practice of blood donation among undergraduate students of Ebonyi State University Abakaliki, southeast Nigeria.

Methods: A descriptive cross sectional study design was employed. A three stage sampling technique was used to select 300 students of the institution. Information was obtained using a self-administered questionnaire. Outcome measure of the study is the proportion of the students that has ever donated blood. Good knowledge of blood donation was determined by the proportion of students who correctly answered seven of the ten variables used to assess knowledge.

Results: The mean age of the students was $23.2 \pm 3.0$ years and majority, $60 \%$ were females. Majority, $86.7 \%$ were aware of blood donation. Majority, $69.3 \%$ had good knowledge of blood donation. A minor proportion, $36.3 \%$ were certain blood in blood bank were safe, while $59.3 \%$ were willing to donate blood in the future. A minor proportion, 13.3\% have ever donated blood of which $55 \%$ of them have donated once. Major reasons for not donating blood included fear, $53.8 \%$, no interest/ignorance, $19.6 \%$ and cultural/ religious belief, 9.2\%. Predictors of being a blood donor included being male, (AOR=3.8; 95\% $\mathrm{Cl}: 1.7-8.2)$, willingness to donate blood in future, $(\mathrm{AOR}=3.1 ; 95 \% \mathrm{Cl}: 1.3-7.5)$ and being of low socio-economic status, (AOR=0.4; 95\% Cl:0.2-0.9).

Conclusions: Majority of respondents had good knowledge of blood donation but only a minor proportion has ever donated blood, however, majority were willing to donate blood in the future. The major barriers to the practice of blood donation among the students were based on misconceptions and lack of information. There is the need for adequate public enlightenment and regular blood donation awareness campaigns in the university and the society at large. The aim of such campaigns which should emphasize the benefits of blood donation would be to target those who are willing to donate blood in the future as they could be the mainstay of blood donation if properly motivated especially in developing countries.

\section{Introduction}

Human blood is an important element of human life [1]. Incidentally, there is no substitute to blood hence donation of blood by humans is of utmost importance [2]. Presently, it is the most donated tissue in medical practice and the ability to transfuse blood and its components is regarded as one of the great advances in modern medicine [3]. Blood transfusion service is thus becoming an indispensable component of health care and has been so useful and life-saving in both routine and emergency situations [4]. It is estimated that an approximate $25 \%$ of maternal deaths could be prevented by the availability of safe blood [5,6]. Interestingly, advances in clinical science and the attendant increase in the population of the world has further increased the need for blood.

In-spite of the relevance of blood donation, the major challenge to the transfusion of blood is meeting the increasing demand for blood and ensuring its constant supply. Also, the use of blood and blood products may also be associated with complications some of which could threaten life. The donation of blood by individuals for the purpose of transfusion is influenced by several factors including altruism, social pressure, behaviour and replacement needs [7,8]. Blood donors could be categorized into three including voluntary non-remunerated, family or replacement and remunerated or paid. The safest donors are those who donate blood voluntarily 
primarily motivated by altruism and this is because they are aware they could be unsuitable to serve as blood donors when there is a risk of causing harm to the recipients [9]. Unfortunately, the recruitment of voluntary, non-remunerated blood donors poses major challenges to transfusion services throughout the world [10].

There is evidence that the donation of blood is safe and of good effect to the donor, recipient, community and the blood transfusion service [11-13]. It has also been found that voluntary blood donation benefits the donor medically as it reduces insulin resistance thus improving the glucose balance in the body [14]. Regardless of these facts, several misconceptions, inadequate knowledge and negative attitudes affect the practice of blood donation $[11,15,16]$. The World Health Organization has posited that blood donation by $1 \%$ of the population is the minimum that could meet the most basic requirements of blood for any country [17]. Incidentally, the rate of blood donation is closely related to level of development with the low income countries having the least when compared with high and middle income countries [18].

As a way of recognizing voluntary blood donors, the World Health Assembly officially designated the $14^{\text {th }}$ day of June every year as World Blood Donor day. The day has also been used to encourage more people to become regular blood donors. Based on the relevance of blood to human life, motivation, recruitment and retention of voluntary blood donors are important to achieve safe blood donation as they are considered to be the safest source [19]. The World Health Organization is of the opinion that more young people donate blood in low and middle countries than in high income countries. This necessitates that demographic information of blood donors is of relevance in the formulation of strategies for the recruitment of donors [18].

This has informed the decision of the World Health Organization in encouraging countries in the world to focus on young generation in-order to achieve $100 \%$ voluntary unpaid blood donors [17]. In every country of the world, undergraduate students constitute a huge portion of this group. This study was designed to determine the factors affecting the practice of blood donation among undergraduate students of Ebonyi State University Abakaliki, southeast Nigeria.

\section{Methodology}

\section{Setting}

Ebonyi State was created on the first day of October 1996 out of the present Enugu and Abia states in southeast Nigeria. The Abakaliki campus of the then Enugu State University of Technology was upgraded to Ebonyi State University College by the State Edict of 1998 and it remained affiliated to its parent university until 1999 when it became a full-fledged university.

Study design: This was a descriptive cross-sectional study

\section{Study participants}

The study population were undergraduate students of Ebonyi State University Abakaliki, southeast Nigeria. For inclusion in the study, the student must have stayed more than one full academic year in the university.

\section{Study instrument}

The study instrument was a pre-tested, semi-structured questionnaire which was developed by the researchers. The questionnaire was self-administered. It elicited questions on the socio-demographic characteristics of respondents, knowledge and practice of blood donation and the reason for donating and not donating blood.

\section{Sample size determination}

The minimum sample size for the study was determined by the formula used for single proportions. [20] A sample size of 300 students was used in the study based on a type 1 error $(\alpha)$ of 0.05 , a tolerable margin of error of 0.05 and the proportion of $15 \%$ that had donated blood in a previous study [11].

\section{Sampling technique}

A three stage sampling technique was employed in the study. In the first stage a simple random sampling technique of balloting was used to select three out of the eight faculties in the university. In the second stage, a simple random sampling technique of balloting was used to select two departments in each of the three selected faculties. In the third stage, a systematic random sampling technique was used to select the respondents. The number of undergraduate students present on the day of data collection in the two departments selected for each of the faculties was recorded. By dividing this number by fifty a sampling interval was obtained. (Each of the faculties contributed fifty students for the study). The index student was selected by a simple random sampling technique of balloting. All first year students of the university were excluded from the study.

\section{Data analysis}

Data entry and analysis were done using Statistical Package for Social Sciences (SPSS) version 22. Frequency tables and cross tabulations were generated. Chi square test of statistical significance and multivariate analysis using binary logistic regression were used in the analysis and the level of statistical significance was determined by a p value of less than 0.05 . In determining the predictors of being a blood donor, variables that had a p value of less than 0.2 on bivariate analysis were entered into the logistic regression model. The results were reported using adjusted odds ratios (AOR) and 95\% confidence interval.

\section{Ethical approval}

Ethical approval for the study was obtained from the Research and Ethics Committee of Ebonyi State University Abakaliki, southeast Nigeria. The students were required to sign a written informed consent form before participating in the study. Participation in the study was voluntary and participants were assured that there would be no victimization of any student who did not want to participate or who decided to withdraw after giving consent. 


\section{Results}

Table 1 shows the socio-demographic characteristics of

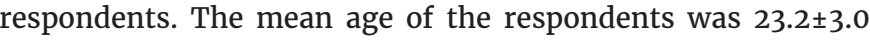
years and a higher proportion of the respondents, $69.3 \%$ were less than 25 years. Majority of the respondents, $60.0 \%$ were females.

Table 2 shows the knowledge of blood donation among the respondents. Majority of the respondents, $86.7 \%$ were aware of blood donation and a higher proportion of the respondents, $84.7 \%$ knew their blood group. Majority of the respondents, $73.0 \%$ were aware of where to donate blood. A higher proportion of the respondents, $69.3 \%$ had good knowledge of blood donation.

Table 1: Socio-demographic characteristics of respondents

\begin{tabular}{|c|c|c|}
\hline Variable & Frequency $(n=300)$ & Percent (\%) \\
\hline \multicolumn{3}{|l|}{ Age (years) } \\
\hline Mean $\pm(S D)$ & $23.2 \pm 3.0$ & \\
\hline \multicolumn{3}{|l|}{ Age of respondents in groups } \\
\hline$<25$ years & 208 & 69.3 \\
\hline$\geq 25$ years & 92 & 30.7 \\
\hline \multicolumn{3}{|l|}{ Gender } \\
\hline Male & 120 & 40.0 \\
\hline Female & 180 & 60.0 \\
\hline \multicolumn{3}{|l|}{ Ethnicity } \\
\hline Igbo & 296 & 98.7 \\
\hline Others ${ }^{\star \star}$ & 4 & 1.3 \\
\hline \multicolumn{3}{|l|}{ Educational attainment of Father } \\
\hline No formal education & 27 & 9.0 \\
\hline Primary education & 75 & 25.0 \\
\hline Secondary education & 80 & 26.7 \\
\hline Tertiary education & 118 & 39.3 \\
\hline \multicolumn{3}{|l|}{$\begin{array}{l}\text { Educational attainment of } \\
\text { Mother }\end{array}$} \\
\hline No formal education & 26 & 8.7 \\
\hline Primary education & 79 & 26.3 \\
\hline Secondary education & 81 & 27.0 \\
\hline Tertiary education & 114 & 38.0 \\
\hline \multicolumn{3}{|l|}{ Employment status of Father } \\
\hline Self employed & 188 & 62.7 \\
\hline Salaried employment & 112 & 37.3 \\
\hline \multicolumn{3}{|l|}{ Employment status of Mother } \\
\hline Self employed & 201 & 67.0 \\
\hline Salaried employment & 99 & 33.0 \\
\hline \multicolumn{3}{|l|}{ Location of secondary school } \\
\hline Urban & 175 & 58.3 \\
\hline Rural & 125 & 41.7 \\
\hline \multicolumn{3}{|l|}{ Socio-economic status } \\
\hline Low socio-economic status & 151 & 50.3 \\
\hline High socio-economic status & 149 & 49.7 \\
\hline
\end{tabular}

Table 2: Knowledge of Blood Transfusion among the respondents. Variable Frequency $(n=300)$

Aware of blood donation

\begin{tabular}{|c|c|c} 
Yes & 260 & 86.7 \\
\hline No & 40 & 13.3 \\
\hline
\end{tabular}

Knowledge of one's blood group

\begin{tabular}{|c|c|c|}
\hline Yes & 254 & 84.7 \\
\hline No & 46 & 15.3 \\
\hline
\end{tabular}

HIV could be transmitted by blood donation

Yes

No

7.0

Hepatitis could be transmitted by blood donation

Yes

No

Malaria could be transmitted by blood donation

Yes

No

Aware blood is screened before transfusion

Yes

No

Males and females can donate blood

Yes

No

11.0

Aware of where to donate blood

Yes

No

Blood donation is harmful to the donor

Correct

Incorrect

Aware of blood donation awareness campaigns

\begin{tabular}{|l|l|l} 
Yes & 134 & 44.7 \\
\hline No & 166 & 55.3 \\
\hline
\end{tabular}

Blood could be donated more than once in a year

$$
\text { Yes }
$$

No

Knowledge of blood donation

Good knowledge

Table 3 shows the willingness to donate blood among the respondents. A minor proportion of the respondents were willing to receive blood when the need arises while the majority of the respondents, $80.7 \%$ were willing to donate blood to a relative. A higher proportion of the respondents, $59.3 \%$ were willing to donate blood in the future while a minor proportion, $36.3 \%$ were of the opinion that blood in blood bank is safe. 
Table 4 shows the practice of blood donation among the respondents. A minor proportion, $13.3 \%$ has ever donated blood, however majority of those who have donated blood, $75.0 \%$ did that on voluntary basis. The major reason for donating blood, $52.5 \%$ was to save lives while fear, $53.8 \%$ was the major reason for not donating blood.

Table 5 shows the factors affecting the donation of blood by the respondents. The male students were about four times more likely to be a blood donor when compared with the female students, (AOR 3.8, 95\% CI: 1.7-8.2). Also, the students who were willing to donate blood in the future were three times more likely to donate blood when compared with those who were not willing. (AOR 3.1, 95\%CI: 1.3-7.5). The students who were in the low socio-economic group were 2.5 times less likely to be a blood donor when compared with those in the high socio-economic group. (AOR 0.4, 95\%CI: 0.2-0.9).

\section{Discussion}

Majority of the respondents, $86.7 \%$ were aware of blood donation. This was expected bearing in mind the level of education of the respondents. In another study among undergraduates in a Nigerian university, $88.5 \%$ of the respondents have also heard of blood donation [21]. The high level of education of the respondents could also explain why a very high proportion of the students were aware of their blood groups and where to donate blood. Interestingly, majority of the respondents, $69.3 \%$ had good knowledge of blood donation. This finding is similar to that observed in a study

Table 3: Willingness to donate blood among the respondents.

\begin{tabular}{|l|l|l}
\hline Variable & Frequency $(\mathrm{n}=\mathbf{3 0 0})$ & Percent $(\%)$
\end{tabular}

Willingness to receive blood when in need

\begin{tabular}{|l|l|l|}
\hline Yes & 136 & 45.3 \\
\hline No & 164 & 54.7 \\
\hline
\end{tabular}

Willingness to donate blood to a relative

\begin{tabular}{|c|c|c|} 
Yes & 242 & 80.7 \\
\hline No & 58 & 19.3 \\
\hline
\end{tabular}

Willingness to donate blood to someone you do not know

Yes

No

Ever encouraged anyone to donate blood

\begin{tabular}{|l|l|}
\hline Yes & 101 \\
\hline No & 199 \\
\hline
\end{tabular}

Willing to donate blood in the future

\begin{tabular}{|l|l|l|}
\hline Yes & 178 & 59.3 \\
\hline No & 122 & 40.7 \\
\hline
\end{tabular}

Should blood donors be remunerated

\begin{tabular}{|c|c|c|} 
Yes & 97 & 32.3 \\
\hline No & 203 & 67.7 \\
\hline
\end{tabular}

Blood in blood bank is safe

$$
\text { Yes }
$$

No

191
Table 4: Practice of blood donation among the respondents.

\begin{tabular}{|c|c|c|}
\hline Variable & Frequency $(n=300)$ & Percent (\%) \\
\hline \multicolumn{3}{|l|}{ Ever donated blood before } \\
\hline Yes & 40 & 13.3 \\
\hline No & 260 & 86.7 \\
\hline $\begin{array}{c}\text { Number of times blood has been } \\
\text { donated }\end{array}$ & $(n=40)$ & \\
\hline Once & 22 & 55.0 \\
\hline Twice & 13 & 32.5 \\
\hline$>2$ times & 5 & 12.5 \\
\hline \multicolumn{3}{|l|}{ Type of Blood donation } \\
\hline Voluntary & 30 & 75.0 \\
\hline Not voluntary & 10 & 25.0 \\
\hline Reason for donating blood & $(n=40)$ & \\
\hline Save lives & 21 & 52.5 \\
\hline Lack of blood/Emergency & 8 & 20 \\
\hline Financial incentive & 3 & 7.5 \\
\hline No specific reason & 8 & 20.0 \\
\hline Reason for not donating blood & $(n=260)$ & \\
\hline Fear /uncertainty & 140 & 53.8 \\
\hline No interest/ignorance & 51 & 19.6 \\
\hline Cultural/religious beliefs & 24 & 9.2 \\
\hline No encouragement for donors & 19 & 5.3 \\
\hline No specific reason & 26 & 10.0 \\
\hline
\end{tabular}

among undergraduate students in another Nigerian university [11], but higher than that obtained from other studies [21-23].

The finding that majority of undergraduate students in this study had good knowledge of blood donation is commendable as this may be the means to correct the several misconceptions that are associated with blood donation. This is important bearing in mind that the World Health Organization has affirmed that young people which includes undergraduate students are the main blood donors in developing countries [18].

A higher proportion of the respondents were willing to donate blood to a relative, $(80.7 \%)$ or to someone they do not know, $67.7 \%$ when compared to those who were willing to receive blood when in need, $45.3 \%$. This could be an expression of lack of trust in the practice of blood donation and of the blood bank system in the country. This was further confirmed by the proportion of the students (35.3\%) who were of the opinion that blood in the blood bank is safe. This proportion that attested to the safety of blood in the blood bank is very low when compared to that from a similar study in India [24]. The marked disparity may be an indication that the youths in Nigeria and India perceive the practice of blood donation and issues of blood bank differently. It is however worth recognizing that the respondents in the study in India were students in the medical sciences only.

A minor proportion of the respondents, $13.3 \%$ have ever donated blood. This is similar to that from other studies in Nigeria [11,21], and another in Ethiopia [23], and India [25]. 
Table 5: Factors affecting the donation of blood by the respondents.

\begin{tabular}{|c|c|c|c|c|}
\hline \multirow{2}{*}{ Variable } & \multicolumn{2}{|c|}{ Ever donated blood $(n=300)$} & \multirow{2}{*}{ p value* } & \multirow{2}{*}{$\operatorname{AOR}(95 \% \mathrm{Cl})^{\star *}$} \\
\hline & Yes N(\%) & No N(\%) & & \\
\hline \multicolumn{5}{|l|}{$\begin{array}{l}\text { Knowledge of blood } \\
\text { transfusion }\end{array}$} \\
\hline Good & $34(16.3)$ & $174(83.7)$ & 0.021 & $1.5(0.5-4.0)$ \\
\hline Poor & $6(6.5)$ & $86(93.5)$ & & \\
\hline \multicolumn{5}{|l|}{ Age of respondents } \\
\hline$<24$ years & $13(8.3)$ & $144(91.7)$ & 0.007 & $0.5(0.2-1.1)$ \\
\hline$\geq 24$ years & $27(18.9)$ & $116(81.1)$ & & \\
\hline \multicolumn{5}{|l|}{ Gender of respondents } \\
\hline Male & $27(22.5)$ & $93(77.5)$ & $<0.001$ & $3.8(1.7-8.2)$ \\
\hline Female & $19(7.2)$ & $167(92.8)$ & & \\
\hline \multicolumn{5}{|l|}{ Socio-economic status } \\
\hline $\begin{array}{c}\text { Low socio-economic } \\
\text { status }\end{array}$ & $13(8.6)$ & $138(91.4)$ & 0.015 & $0.4(0.2-0.9)$ \\
\hline $\begin{array}{l}\text { High socio-economic } \\
\text { status }\end{array}$ & $27(18.1)$ & $122(81.9)$ & & \\
\hline \multicolumn{5}{|l|}{$\begin{array}{c}\text { Employment status of } \\
\text { Father }\end{array}$} \\
\hline Self employed & $24(12.8)$ & $164(87.2)$ & 0.708 & NA \\
\hline Salaried employment & $16(14.3)$ & $96(85.7)$ & & \\
\hline \multicolumn{5}{|l|}{$\begin{array}{c}\text { Employment status of } \\
\text { Mother }\end{array}$} \\
\hline Self employed & $24(11.9)$ & $177(88.1)$ & 0.312 & NA \\
\hline Salaried employment & $16(16.2)$ & $83(83.8)$ & & \\
\hline \multicolumn{5}{|l|}{$\begin{array}{l}\text { Location of secondary } \\
\text { school }\end{array}$} \\
\hline Urban & $22(12.6)$ & $153(87.4)$ & 0.646 & NA \\
\hline Rural & $18(14.4)$ & $107(85.6)$ & & \\
\hline \multicolumn{5}{|l|}{$\begin{array}{l}\text { Educational attainment } \\
\text { of Father }\end{array}$} \\
\hline Tertiary education & $15(12,7)$ & $103(87.3)$ & 0.799 & NA \\
\hline $\begin{array}{c}\text { Secondary education } \\
\text { and less }\end{array}$ & $25(13.7)$ & $157(86.3)$ & & \\
\hline \multicolumn{5}{|l|}{$\begin{array}{c}\text { Educational attainment } \\
\text { of Mother }\end{array}$} \\
\hline Tertiary education & $16(14.0)$ & $98(86.0)$ & 0.780 & NA \\
\hline $\begin{array}{c}\text { Secondary education } \\
\text { and less }\end{array}$ & $24(12.9)$ & $162(87.1)$ & & \\
\hline \multicolumn{5}{|l|}{$\begin{array}{l}\text { Willingness to donate } \\
\text { blood in the future }\end{array}$} \\
\hline Yes & $32(18.0)$ & $146(82.0)$ & 0.004 & $3.1(1.3-7.5)$ \\
\hline No & $8(6.6)$ & $114(93.4)$ & & \\
\hline
\end{tabular}

*p value on bivariate analysis; **Adjusted odds ratio (95\% Confidence Interval) NA Not applicable

These proportions were lower than that from the results of other studies. [22,26-28] The differences could be a reflection of the perception of the practice of blood donation in the various societies. Also, among those who donated, majority were first time blood donors and this is similar to the results from other studies also $[23,29,30]$. The explanation for this could be that the donors may have donated blood out of need. It is important to note that after the first donation, the students could also donate again if properly motivated.

The major reason for donating blood among the respondents was to save lives. In a study among undergraduates in a Nigerian university, the major motivation to donating blood by the students was the intention to save lives [11]. Also, the major reason for not donating blood was fear and same result was obtained in other studies $[22,23]$. Even though the practice of blood donation has been adjudged to be safe, people still have many wrong ideas about it $[11,15,16]$. It is also important to note that all the reasons provided by the students for not donating blood could be addressed through public enlightenment with emphasis on the good to be derived from blood donation and this could be done during the blood donation awareness campaigns.

From the results of this study, the male students were about four times more likely to be blood donors when compared with the female students. This is understandable as men are known to have a higher packed cell volume than females. Also, females are exposed to monthly menstrual periods and child delivery all of which result in loss of blood. Moreover due to the monthly menstrual cycles there are times females may not be able to donate blood. The observation that males participate more in blood donation when compared with females is consistent with findings from other studies [21-23,31,32]. However, in a study among university students in Kilimanjaro Tanzania, males students had a lower odds of donating blood than the females [28]. This could mean that females in Tanzania may have more social responsibilities than what is obtained in the other countries under consideration.

The students who were willing to donate blood in the future were three times more likely to be blood donors when compared with those who were not. This is in agreement with the results of a similar study in Tanzania [28]. From the results of this study also, majority of the students were willing to donate blood in the future and this is much higher than the proportion that have actually donated blood. This is also similar to findings from other studies $[28,30,33,34]$. To an extent the future of voluntary blood donation might be closely related to the proportion that are willing to donate blood in the future, implying that they could be the mainstay of blood donation if adequately motivated. Identifying this group may be difficult, however, they could be the target during blood donation awareness campaigns. It has been found that only beliefs in benevolence were associated with the intention to donate blood hence the suggestion that blood donation campaigns should focus on its beneficial aspects [35]. There is evidence that the donation of blood is safe and of good effect to the society as a whole [11-13]. Thus, focusing the message of future blood donation awareness campaigns on the concept that blood is of immense benefit to mankind could appeal to this group of individuals thus leading to increased blood donation in the future especially in developing countries.

The respondents who were in the low socioeconomic group were about three times less likely to donate blood when compared with those in the high socioeconomic group. Socioeconomic status has been found to be associated with the status of being a blood donor [36]. In a study in Pelotas, southern Brazil, the prevalence of blood donation increased with the economic level of the respondents [37]. Similarly, in a study in Denmark, respondents who were in the middle and high income groups but excluding the highest income group had a fourfold higher blood donor prevalence when compared to the lowest income group [38]. Since blood is an essential element of human life [1], it could be that those in the low socioeconomic group are more conservative hence more unwilling to part with something as precious as blood since they may be unsure of its replacement. The difference could 
also be a reflection of the different levels of understanding of the practice of blood donation among those in the low and high socioeconomic groups.

\section{Conclusions}

Majority of respondents had good knowledge of blood donation but only a minor proportion has ever donated blood, however, majority were willing to donate blood in the future. The major barriers to the practice of blood donation among the students were based on misconceptions and lack of information. There is the need for adequate public enlightenment and regular blood donation awareness campaigns in the university and the society at large. The aim of such campaigns which should emphasize the benefits of blood donation would be to target those who are willing to donate blood in the future as they could be the mainstay of blood donation if properly motivated especially in developing countries.

\section{References}

1. Nwogoh B, Aigberadion U, Nwannadi Al (2013) Knowledge, attitude and practice of voluntary blood donation among healthcare workers at the University of Benin Teaching Hospital, Benin City, Nigeria. Journal of Blood Transfusion. Link: https://goo.gl/JHQa1Z

2. Lowe KC, Ferguson E (2003) Benefit and risk perceptions in transfusion medicine: blood and blood substitutes. Journal of Internal Medicine 253: 498507. Link: https://goo.gl/vLDFdz

3. Zmijewski CM, Haesler WE (1982) Blood banking service. Appleton Century Croft. 1982. New York. Link: https://goo.gl/rCA9Vr

4. World Health Organization (2016) Towards $100 \%$ voluntary blood donation, a global framework for action. Available at. Link: https://goo.gl/tVkLVC

5. Hensher M, Price M, Adomakoh S (2006) Referral hospitals. Disease control priorities in developing countries 66: 1229-1212. Link: https://goo.gl/Ljgjj7

6. Weiser TG, Regenbogen SE, Thompson KD, Hayne AB, Lipsitz SR, et al. (2008) An estimation of the global volume of surgery: a modelling strategy based on available data. The Lancet 372: 139-144. Link: https://goo.gl/6AB459

7. Oswalt RM, Hoff TE (1977) The motivations of blood donors and non donors: a community survey. Transfusion 15: 68-73. Link: https://goo.gl/onG2xQ

8. Zaller N, Nelson KE, Ness P, Wen G, Bai X, et al. (2005) Knowledge, attitude and practice survey regarding blood donation in a north western Chinese city. Transfus Med 15: 277-286. Link: https://goo.gl/hRTx9Y

9. Buyx AM (2009) Blood donation, payment and non-cash icentives: classica questions drawing renewed interest. Transfusion Medicine and Hemotherapy 36: 329-339. Link: https://goo.gl/QaWcr6

10. Misie AH, Bosnes V, Heier HE (2010) Gender differences in presentation rates, deferrals and return behavior among Norwegian blood donors. Vox Sang 98: e241-248. Link: https://goo.gl/ueXP5L

11. Salaudeen AG, Odeh E (2011) Knowledge and behavior towards voluntary blood donation among students of a tertiary institution in Nigeria. Niger $J$ Clin Pract 14: 303-307. Link: https://goo.gl/xUuDPg

12. Shenga N, Pal R, Sengupta S (2008) Behavior disparities towards blood donation in Sikkim, India. Asi J Transfus Sci 2: 56-60. Link: https://goo.gl/fB6nAv

13. Amatya M, Gorkhali B, Mahotra N, Prajapati R, Yadav SR (2013) Knowledge, attitude and practice of medical students on blood donation: a comparison between two medical colleges of Nepal. Int J Curr Res 5: 2641-2644. Link: https://goo.gl/g631q9

14. Real JMF, Bermejo AL, Ricart W (2005) Iron stores, blood donation and insulin sensitivity and secretion. Clin Chem 51: 1201-1205. Link: https://goo.gl/B9xpV6

15. Saeed N, Munir E, Shahid R (2011) Beliefs about blood donation among patients visiting OPDs of Pakistani's General Hospitals. JBUMDC 1: 61-67.

16. Alzaben S, Salameh A, Alhiary M (2012) Knowledge and attitude about blood donation among blood donors at King Hussien Medical Centre. Asian J Exp Biol Sci 3: 435-438. Link: https://goo.gl/PL6Vzv

17. World Health Organization (2016) World Blood Donor Day 2016: blood connects us all. Link: https://goo.gl/SB9DKc

18. World Health Organization (2016) Blood safety and availability. Link: https://goo.gl/QrSd1Q

19. Siromani U, Rajaiah M, Daniel D, Mammen JJ, Nair SC (2012) Ahead to $100 \%$ of voluntary non-remunerated blood donation at a tertiary referral hospital blood bank in south India. Asian J Transfus Sci 6: 190. Link: https://goo.gl/rKKivD

20. Taofeek I (2009) Research methodology and dissertation writing for health and allied health professionals. 1st edition. Abuja: Cress Global Link Ltd.

21. Ogunbona OB, Okafor IP, Sekoni AO (2013) Knowledge and practice of blood donation among university undergraduates. High Med Res J 13: 26-30. Link: https://goo.gl/YrhDn8

22. Raghuwanshi B, Pehlajani NK, Sinha MK (2016) Voluntary blood donation among students- a cross-sectional study on knowledge and practice vs. attitude. J Clin Diagn Res 10: EC18-EC22. Link: https://goo.gl/p6Vx7a

23. Ahmed AO (2017) Knowledge, attitude, practice and associated factors of voluntary blood donation among undergraduate students in Hargeisa University. J Community Med Health Edu 7: 547-559. Link: https://goo.gl/qJHrNa

24. Giri PA, Phalke DB (2012) Knowlede and attitude about blood donation amongst undergraduate students of Pravara Institute of Medical Sciences Deemed University of Central India. Ann Trop Med Public Health $5: 569-573$ Link: https://goo.gl/BYXgss

25. Aslami AN, Jobby A, Simon S, Nazarudeen N, Raj P, Ramees $M$, et al. (2015) Assessment of knowledge, attitude and practice (KAP) of blood donation among MBBS students of a medical college in Kollam, Kerala Journal of Evolution of Medical and Dental Sciences 4: 6086-6095. Link: https://goo.gl/KYkLeQ

26. Ciepiela O, Jaworska A, Lacheta D, Faalkowska N, Popko K, et al. (2017) Awareness of blood group and blood donation among medical students. Transfus Apher Sci 56: 858-864. Link: https://goo.gl/xWrzhX

27. Chopra D, Jauhari N (2015) Knowledge attitude \& practices towards voluntary blood donation among medical students in Barabanki. Indian J Comm Health 27: 386-390. Link: https://goo.gl/qDyHzd

28. Elias E, Mauka W, Philemon RN, Damian DJ, Mahande MJ, et al. (2016) Knowledge, attitude. Practices and factors associated with voluntary blood donation among university students in Kilimanjaro, Tanzania. Journal of Blood Transfusion 14: 2016. Link: https://goo.gl/HQH9kA

29. Thakur A, Chauhan HS, Achanya B (2015) Knowledge and practices of blood donation among the undergraduate students of district Una, Himachal Pradesh, India. Global Journal of Medicine and Public Health 4. Link: https://goo.gl/rwrujV

30. Jemberu YA, Esmael A, Ahmed KY (2016) Knowledge, attitude and practice towards blood donation and associated factors among adults in Debre Marks town, Northwest Ethiopia. BMC Hematology 16: 23-30. Link: https://goo.gl/cSjd9Q 
31. Papagiannis D, Rachiotis G,Symvoulakis EK, Anyfantakis D, Douvlataniotis $K$ et al. (2016) Blood donation knowledge and attitudes among undergraduate health science students: a cross-sectional study. Transfusion and Apheresis Science 54: 303-308. Link: https://goo.gl/BzV7f4

32. Ahmed Z, Zafar M, Khan AA, Anjum MU, Siddique MA (2014) Knowledge, attitude and practices about blood donation among undergraduate students in Karachi. J Infect Dis Ther 2: 134. Link: https://goo.gl/5sz2RS

33. Devi HS, Laishram J, Shantibala K, Elangbam V (2012) Knowledge, attitude and practice (KAP) of bood safety and donation. Indian Medical Gazzette 1-6. medind.nic.in/ice/t12/i1/icet12i1p1.pdf. Link: https://goo.gl/5sz2RS

34. Latif MZ, Riaz H, Mujtaba SWA, Nizami R (2017) Blood donation; knowledge attitude and practice of medical students. Professional Med J 24: 370-374.
35. Ferguson E, Farrell K, Lawrence C (2008) Blood donation is an act of benevolence rather than altruism. Health Psychology 27: 327-336. Link: https://goo.gl/xYJqjK

36. Duboz P, Cuneo B (2009) Impact of socioeconomic status on blood donation. Transfus Clin Biol 16: 371-378. Link: https://goo.gl/ci66gn

37. Zago A, Silveira MF, Dumith SC (2010) Blood donation prevalence and associated factors in Pelotas, southern Brazil. Revista de Saude Publica 44 112-120. Link: https://goo.gl/fa2J9w

38. Burgdorf KS, Simonsen J, Sundby A, Rostgaard K, Pedersen OB, et al. (2017) Socio-demographic characteristics of Danish blood donors. PLoS ONE 12 e0169112. Link: https://goo.gl/ohx4ru 